\title{
The Effect of Organizational Commitment and Organizational Citizenship Behavior Toward Service Quality at Universitas Kristen Indonesia
}

\author{
Edison Siregar \\ State University of jakarta \\ Email: edisonsiregar_im12S3@mahasiswa.unj.ac.id, \\ Muchlis R. Luddin \\ State University of Jakarta \\ Email: muchlis-rantoni@unj.ac.id \\ Thomas Suyatno \\ State University of Jakarta \\ Email: thomas.suyatno@yahoo.com
}

\begin{abstract}
The objective of this research is to find out the effect organizational commitment and organizational citizenship behavior towards service quality at Universitas Kristen Indonesia. The research method used was a quantitative method wiht using path analysed design. In collecting the data, 71 employees were chosen from 243 employees randomly to be the sample of this research. The data of the this research were obtained by distrubuting questiinnaires and analyzed them using path analysis. The result shows that there exists a positive direct effect of (1) organizational commitment towards service quality, (2) organizational citizenship behavior towards service quality, and (3) organizational commitment towards organizational citizenship behavior. Therefore, as the conclussion to this research, to improve the service quality of the employee at Universitas Kristen Indonesia, the organizational commitment, and organizational citizenship behavior should be improved.
\end{abstract}

Keyword: organizational commitment, organizational citizenship behavior, service quality.

\section{INTRODUCTION}

The management human resources with good quality, educated, and characteristical is a must for universities as one of the institutions offering educational services, but achieving this is often a challenge for universities. Higher Education is the most strategic educational institution in developing and maintaining the quality of education. To excel in competition, universities must be able to provide quality services, as it is said by Djati (2011: 12) that In order to achieve the highest service quality performances, it is needed the understanding of what the customers needs and wants together with how to deliver the excellent services based on the customer expectations. It means that in order to achieve the highest service quality performance, an understanding of what the customers' needs and desires are needed together with how to provide the best service based on customer expectations. In observing and interviewing customers conducted on-the-spot at Universitas Kristen Indonesia (UKI) Jakarta, many complaints were directed at the quality of services received from employees, including: employees are less friendly, less sympathetic, less polite in communication, they are difficult to meet when they are needed, and less responsive to complaints. If this is allowed, it will have an impact on the decline in competitiveness for universities. As a higher education service industrial actor, it should carry out a service process that can ensure good service 
quality because service quality is one of the competitive advantages that plays an important role in both the service industry and manufacturing industries. This statement is reinforced by Ahmadia (2017: 40) in his research saying that competitive advantage and service quality are significantly correlated with visitor loyalty to tourist objects both directly and indirectly.

The Qsworld version of university ranking data shows that, in 2014, UKI was in the $147^{\text {th }}$ position. In 2015 , UKI was ranked $135^{\text {th }}$ based on ratings from the Directorate General of Ministry of Reseach, Technology and Higher Education, in 2016, the ranking of UKI dropped in to rank $164^{\text {th }}$, and in 2017 , this rank rose $158^{\text {th }}$. Re-accreditation of tertiary institutions in 2016/2017, UKI has regained "B" for its accreditation (Kopertis, 2014). The data shows a decline in the quality of services at UKI, and it is necessary to strive to improve the quality of services that have competitive advantages. According to Hui, et al., in Djati (2014: 6) that it is necessary to measure through continuous surveys and lead to knowledge about the level of customer satisfaction with the services provided.

Universities need to know what factors influence service quality are. Theoretically and based on previous research studies, there are quite a number of factors that can affect the service quality, including organizational commitment and organizational citizenship behavior (Bahrami et. Al., 2016: 97; Setiawan, 2015: 27; Nurandini and Laturava, 2014: 2; Wagner \& Hollenbeck, 2010: 101; Adekola, 2012: 3; Nengsih, Hadyanto \& Murni, 2013: 932; Chip, 2016: 63; Sucahya \& Suana, 2016: 7332). In its 63-year-old journey, UKI faced various challenges both externally and internally. Challenges that affect many developments, this can be seen that employees still lack of discipline as it is expected by the UKI's regulation in 2015, doing work only as an "attempt to abort obligations" and less responsible for work. In addition, although most employees have a long working period of more than 30 years and an average age of 40 years, but they do not show high morale and have no sense of responsibility towards the organization. Another most influential problem is that the Organizational Citizenship Behavior (OCB) which is in the UKI is till having no support on effectiveness of work, simply, they are still individual worker, less cooperation as team, being jealous of other employees and still cannot accept a difference.

There have been enough studies conducted on these variables; organizational commitment and OCB aimed at service quality, but what is done for employees in a service industry such as private universities is still lack even though employees are an important factor besides educators which affect the level of competitive advantage of universities in global competition. Thus researchers are interested in conducting dissertation research with the title: The effect of organizational commitment and organizational citizenship behavior toward service quality at indonesian christian universities. With the aim of knowing: a) Is there a direct effect of organizational commitment on service quality; b) Is there a direct influence of OCB on service quality; c) Is there a direct influence on organizational commitment to OCB.

The novelty in this study can be seen from the findings based on the analysis conducted on the variables of organizational commitment, organizational citizenship behavior (OCB), and service quality, where OCB is a mediating variable so that the results of both direct and indirect effects on service quality are known.

\section{LITERATURE REVIEW}

Quality service plays an important role in performing customer satisfaction, while also having an impact on creating profits for the company. The more quality services provided by the company, the more satisfaction felt by customers (Panjaitan \& Yuliati, 2016: 266). Kotler quoted by Nuhung (2011: 117) says "customer satisfaction is the level of one's feelings after comparing the performance (results) that are felt compared to expectations. To see how important service quality is for an organization, you need to know what factors affect it. One of the dominant factors that can affect service quality is the behavior of employees of the organization. This is in accordance with what was said by Kamalinasab, Sami and Zendedel (2017: 1248) that "One of the most important factors affecting service quality is employees' behavior in the organization. In fact, activities of internal staff link the organization with its customers." One example is customer service (Sugiyah, 2018: 62). Two main factors that 
influence service quality are expected service and perceived service. If the service received, or perceived (perceived service) is as expected, the quality of service is perceived as good or satisfying, and vice versa versa (Khoirista, Yulianto \& Mawardi, 2015: 2). There are four characteristics of services, namely; intangibility, variability, inseparability, and perishability. Services are a complicated phenomenon. The word service according to Jasfar quoted by Handayani (2013: 32) has many meanings and scope, from the simplest understanding, namely only in the form of service from someone to others, it can also be interpreted as starting from services provided by humans, both those who seen (explicit service) or that cannot be seen, which can only be felt (implicit service) to supporting facilities that must be available in the sale of services and other objects.

According to Ratminto in Fatrunisah (2015: 237) and Titisari (2014: 86) said service is an activity or series of activities that are invisible (inaccessible) that occur due to interactions between consumers and employees or other things provided by the service organization that is intended to solve the problem of consumers or customers. Quality is a very dominant factor in the success of an organization. The American Society for Quality Control cited Kotler \& Keller (2012: 131), Soleimani, Khosravi \& Mohammadi (2017: 922), Murni (2011: 103) and Huang \& Lee (2015: 108) stated "Quality is the totality of features and characteristics of a product or service that bear on its ability to satisfy stated or implied needs." Some people think of qualities such as excellence, zero defects, product prices, also other things such as: (a) perfection; (b) consistency; (c) eliminating waste; (d) speed of delivery; (e) compliance with policies and procedures; (f) providing a good, usable product; (g) doing right the first time. Lewis and Booms in Harjati and Venice (2015: 65), Luthans (2011: 39), and Mmatle \& Shonhe (2017: 2) define service quality as a measure of how well the level of service provided is in line with customer expectations. Another dimension of service quality was delivered by Ogunnaike (2011: 35) who divided it into the following two categories: a) enhancing factors, b) dual threshold factors.

The service quality measurement model was developed by Parasuraman, Zeithaml, and Berry (1998: 23) so that it became 5 (five) dimensions i,e tangible, reliability, responsiveness, assurance, and empathy.

Based on the description above, it can be synthesized that service quality is a match between expectations and reality of services received by customers, with indicators: (1) tangibles; (2) reliability; (3) responsiveness; (4) assurance; (5) empathy.

Commitment is a combination of self-confidence and motivation and enthusiasm of employees as well as employee development on the tasks handled. This is also an ongoing process where members convey their concern for the organization, success and progress that is sustainable (Setyaningrum, 2017: 557). While according to Robbins and Judge (2013: 109), organizational commitment is "the degree to which an employee identifies with a particular organization and its goals and wishes to maintain membership in the organization". Organizational commitment is an encouragement in the individual to do something in order to support the success of the organization with the aim and prioritize the interests of the organization (Putra, 2017: 2340; Rusyandi, 2016: 8).

This understanding shows that organizational commitment is the extent to which employees identify the organization and its desire to continue to actively participate in it. Often reflects employees' trust in the company's mission and goals, willingness to develop business in the completion of their work and the desire to continue working in the organization. Organizational commitment can also be said as a strong desire for someone to continue together and connect with the organization and strive to help the organization achieve its goals. This statement is supported by Aledeinat and Alrfou (2017: 3) who quote Porter and Steers, who say "The relative strength of the relationship between an individual and an organization often characterized by a strong belief in and the acceptance of the organization's norms and goals, strong drive to continue being a member of the organization and the willingness to go extra miles for the organization is regarded as organizational commitment".

Organizational commitment as a good introduction to the organization so that employees will be willing to develop a business to achieve the goals and mission of the organization, and want to become members of the organization for a long time. This is in line 
with what was stated by Wagner \& Hollenbeck (2010: 111) and Khaleh \& Naji (2016: 173) who say "Organizational commitment is the degree to which people identify with the organization that employs them. It implies a willingness on the employee's part to put forth a substantial effort on the organization's behalf and his or her intention to stay with the organization for a long time". Organizational commitment is the degree to which an individual identifies himself with an organization, participates and engages in certain organizations and this level is measured through three elements that define identity, work participation and involvement and loyalty to the organization. The definition above reflects the attitude of employee loyalty to the organization and is an expression of its concern for the organization and its continued success and progress. In this sense there are three indicators of organizational commitment, namely: (1) a strong desire to remain as a member of a particular organization; (2) the desire to strive according to the wishes of the organization; and (3) certain beliefs, and acceptance of organizational values and objectives. Meanwhile, Colquitt, Lepine, and Wesson (2011: 68) say "Organizational commitment is defined as the desire on the part of an employee to remain a member of the organization".

Organizational commitment is defined as the desire of some employees to remain members of the organization. Organizational commitment influences whether an employee stays as a member of the organization or leaves an organization member to look for another job. Ortiz et al. (2015: 93) say that the organizational commitment is formed when employees and organizations foster greater interest in maintaining their working relationships. Employees experience a level of loyalty related to their ties to the organization, and their willingness to continue to participate or work with them. Organizational commitment is the emotional relationship that employees feel with their work. While George and Jones (2012: 71) and Mcshane \& Glinow (2010: 122) say organizational commitment is "... is the collection of feelings and beliefs that people have about their organization as a whole". Employees who have a high commitment to the company tend to show good quality, more totality in work and the turnover rate for the company is also low (Akbar et al., 2017: 33). Newstroom in Apriliana, Hamid, and Hakam (2013: 21) said that conceptually, organizational commitment is characterized by three things: (1) a strong sense of trust and acceptance of the goals and values of the organization; (2) the desire of someone to do business seriously for the sake of the organization; and (3) there is a strong desire to maintain membership in an organization. Meyer and Allen in Prabhakar and Ram (2011: 55) concluded that an employee's commitment reflected a desire, need and obligation to maintain membership in an organization.

There are two main dimensions of organizational commitment. Rational commitment, reflects that work provides services to financial interests, development, individual professional interests. Emotional commitment reflects the feeling that what someone is doing is important, valuable, and provides real benefits to others. Evidence that strong emotional commitment to the organization is based on the values and interests of others and gives a 4fold positive influence on performance rather than rational commitment, which is based on pay and self-interest (Wibowo, 2015: 188).

Based on the description above, it can be synthesized that organizational commitment is the attachment of employees to their roles and functions as members of the organization as indicated by the acceptance of organizational values and objectives and having a desire to be affiliated with the organization as measured by indicators: 1) Desire; 2) Need; and 3) Obligation.

Improving the performance of an organization is strongly influenced by the quality of behavior of employees in it. This behavior is expected not only to relate to the quality of the implementation or tasks assigned as inrole of behavior, but more than that also behavior that is extra role or not outlined in the organization's job description and is able to make a positive contribution to the effectiveness of the organization. This extra role behavior became known as OCB. The productivity of the company depends on the contribution and performance that the employee gives to the company or organization. Employee performance is a dependent variable, so that the condition of employee performance in the organization cannot be separated from other factors. Especially in service companies, then one of the factors that 
influence the high and low of employee performance is extra role behavior or commonly called OCB (Hapsari, 2010: 13).

Some experts gave opinions on OCB, including Organ and Konovsky quoted by Rahayu (2016: 17), saying "OCB are those voluntary, "above the call of duty" behavior that some feel not only contribute to company success but are necessary for success. The OCB can include "talking up" the firm too outsiders, helping co-worker, and offering useful suggestion". It means that OCB is voluntary "over the call of duty", a behavior in which some people feel that not only contributes to the success of the institution or company but is needed for success, OCB can include "discussing success" institutions / outsiders, helping friends work, and offer useful advice. Another opinion says that OCB is free individual behavior, not directly or explicitly recognized in the reward system and in promoting the effective functioning of the organization or in other words OCB is the behavior of employees that exceeds the required role, which is not directly or explicitly recognized by the system formal reward (Ticoalu, 2013: 784).

Aldag and Reschke in Darto (2014: 13) define OCB as “....are individual contributions in the workplace that beyond role requirements and contractually rewarded job achievements. This would include such behaviors as helping others, volunteering for extra-job activities, and upholding workplace rules and procedures regardless of personal inconvenience. These behaviors represent "employee value added" which is not reflected in traditional narrower performance measures." This view suggests that OCB is the contribution of individuals in the workplace that goes beyond the role role and achievement of work that is contractually rewarded. These behaviors illustrate the added value of employees that are not reflected in traditional narrow performance measures. Meanwhile, Ivancevich, Konopaske and Matheson (2005: 267) state that "being civilized or polite towards other people in an organization is something that is liked and forms what some people call organizational citizenship behavior.

According to Tambe and Shanker (2014: 67) who cite the Organ, interpreting OCB as "represents individual behavior that is discretionary, not directly or explicitly recognized by the formal reward system, and in the aggregate promotes the efficient and effective functioning of the organization." OCB is an individual behavior that is voluntary, not directly or explicitly recognized by the formal reward system and as a whole can improve the efficiency and effectiveness of organizational functions. Organ in Iliea (2014: 489), defines OCB as "... Individual behavior that is not explicitly or indirectly recognized by the formal reward system and that behavior play a vital role in the effective functioning of the organization." It has as well as those of its environment, it is hoped that it can be used to maintain and improve social interaction better.

While Organ et al. proposes five dimensions of OCB, namely: (1) Altruism, is the behavior of employees in helping colleagues who experience difficulties in the situation being faced both regarding tasks in the organization and personal problems of others. This dimension leads to giving help which is not an obligation that is borne by it; (2) Conscientiousness, is behavior that is shown by trying to exceed what is expected by the company, for example the efficiency of using time and exceeding expectations, voluntary behavior which is not an obligation or duty of employees. This dimension reaches far above and far ahead of the call of duty; (3) Sportsmanship, is a behavior that tolerates less ideal conditions in the organization without raising objections. Employees will be more polite and cooperate with others so that it will create a more pleasant work environment; (4) Courtesy, is to maintain good relations with colleagues to avoid interpersonal problems. Someone who has this dimension is someone who respects and cares for others; (5) Civic virtue, a behavior that indicates responsibility for the life of the organization. This dimension leads to the responsibility given by the organization to a person to improve the quality of the field of work involved (Djati, 2014: 27). Others also found that OCB employees, when collected over time, influenced organizational effectiveness (Ghanbari \& Eskandari, 2014: 2).

Based on the theory discussed above, it can be synthesized that OCB is an individual work contribution that exceeds formal work requirements carried out voluntarily and is not related to the reward system with indicators consisting of: 1) altruism; 2) conscientiousness; 3) sportsmanship; 4) courtesy; and 5) civic virtue. 
In this section will be elaborated some various studies which are relevant to the problems examined in this study. This is intended to obtain accurate information and provide a clear position and relationship between these studies with this research: a) Research conducted by Amri \& Shabri (2015: 180-188) with the title "Contributions to Job Satisfaction, Organizational Climate and Organizational Commitment Against the quality of Medical Services at the Regional Public Service Agency (BLUD) of the Aceh Mental Hospital. "; b) Research conducted by Somad (2013: 320-341) with the title "Effect of organizational culture and organizational commitment on the service quality of four-star hotel employees in the city of Bandung". The population in the study were 170-star four-star customer service hotel employees in Bandung city; c) Other research conducted by Ogunnaike (2011: 33-39) which took the title "Assessing the Effect of Organizational Commitment on Service Quality; a Study of Customer-Contact Employee ". This study focuses on the effect of organizational commitment on service quality and the data needed for this study was collected through a questionnaire instrument. Three hypotheses are formulated and tested using multiple regression. Each hypothesis examines the effect of affective commitment, ongoing commitment and normative commitment to service quality.

Luthans states that as an attitude, organizational commitment is often defined as aspects that mark the high level of one's commitment to the organization, namely: (1) a strong desire to remain a member of a particular organization (a strong desire to remain a member of the organization) ; (2) a willingness to express high levels of effort on behalf of the organization (willingness to mobilize all of its capabilities for the organization); and (3) a definite belief in, and acceptance of, values and goals of the organization (deep belief and acceptance of the values and goals of the organization). Based on the description, it can be assumed that organizational commitment has a positive direct effect on service quality. OCB is free individual behavior, which is not directly or explicitly recognized by the reward system and in promoting the effective functioning of the organization (Ticoalu, 2013: 784), or in other words, OCB is the behavior of employees that exceeds the required role, which is not directly or explicitly recognized by the formal reward system. Based on this description, it can be assumed that OCB has a positive direct effect on service quality. Schermerton, et al. say "Organizational commitment is the loyalty of individuals to the organization. Individuals with a high organizational commitment identify strongly with the organization and take pride in considering themselves a member. Organizational commitment as someone's loyalty to the organization. From this description, it can be assumed that organizational commitment has a direct positive effect on OCB.

Based on the theoretical framework and frame of mind, the research hypothesis can be formulated as follows: a) Organizational Commitment has a direct positive effect on service quality; b) Organizational Citizenship Behavior has a direct positive effect on service quality; c) Organizational Commitment has a direct positive effect on Organizational Citizenship Behavior.

\section{METHODOLOGY}

This study used a quantitative approach through survey methods and path analysis techniques carried out at Universitas Kristen Indonesia (UKI). The variables in this study consisted of endogenous variables, namely service quality and exogenous variables, namely organizational commitment and OCB which are described in the following diagram in table 1.

Table 1. Operational Variable

\begin{tabular}{|l|l|l|l|}
\hline No. & Variable & Indicator & Reference \\
\hline 1. & Service Quality & $\begin{array}{l}\text { - Tangibles } \\
\text { - Reliability } \\
\text { - Responsiveness } \\
\text { - Assurance } \\
\text { - Emphaty }\end{array}$ & $\begin{array}{l}\text { Parasuraman, Zeithaml, dan Berry } \\
\text { in Journal of Retailing (1998) }\end{array}$ \\
& & $\bullet$ Desire & $\begin{array}{l}\text { Allen, N. J. \& Meyer, J. P. (1990) } \\
\text { Prabhakar and Ram (2011) }\end{array}$ \\
\hline 2. & $\begin{array}{l}\text { Organizational } \\
\text { Commitment }\end{array}$ & & \\
\hline
\end{tabular}




\begin{tabular}{|c|c|c|c|}
\hline & & $\begin{array}{ll}\text { - } & \text { Needs } \\
\text { - Obligation }\end{array}$ & \\
\hline 3. & $\begin{array}{l}\text { Organizational } \\
\text { Citizenship } \\
\text { Behavior (OCB) }\end{array}$ & $\begin{array}{l}\text { - Altruism } \\
\text { - Conscientiousness } \\
\text { - Sportmanship } \\
\text { - Courtesy } \\
\text { - Civic Virtue }\end{array}$ & Djati, S. P. (2014). \\
\hline
\end{tabular}

This can be seen in the constellation of relations between variables, as can be seen in figure 1 below.

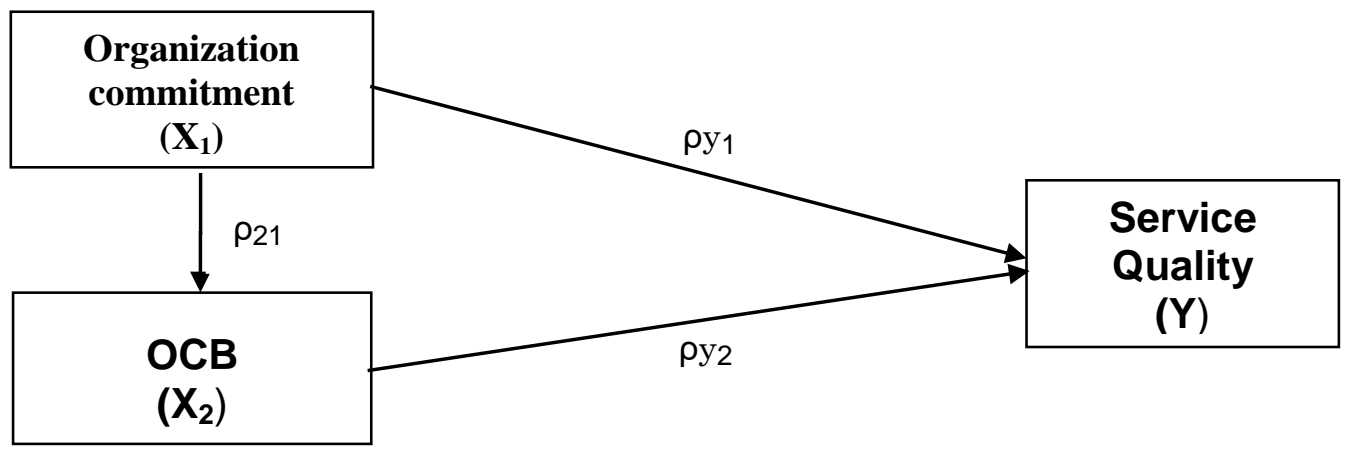

\section{Figure 1. Constellation of Influence Pathways among Research Variables}

In this study, the population is the employees of the faculties and units of UKI, which amount of 243 people. To determine the number of samples taken, the Yamane formula is used as follows.

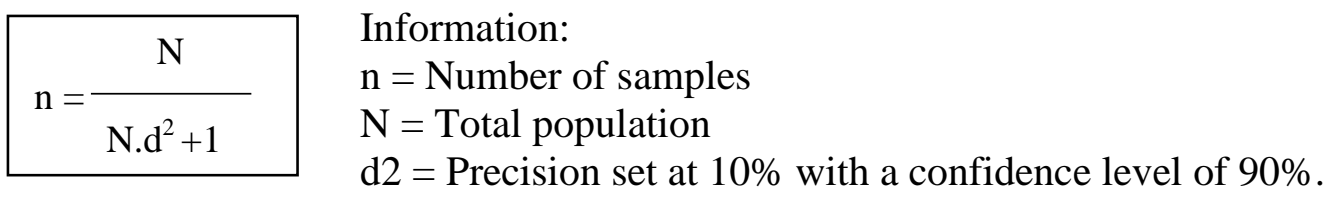

Based on the formula above, the research sample amounts to:

$$
\mathrm{n}=\frac{234}{(234) \cdot(0,1)^{2}+1}=70 \cdot 26=71 \text { persons }
$$

From the results of the calculation, then the number of each sample is determined according to the unit or faculty in a proportionate random sampling formula:

$$
\mathrm{ni}=\frac{\mathrm{Ni}}{\mathrm{N}} \mathrm{n}
$$

Information:

$\mathrm{ni}=$ Number of sample based on the stratum

$\mathrm{n}=$ Total number of sample

$\mathrm{Ni}=$ Number of population based on the stratum

$\mathrm{N}=$ Total number of population

With this formula, the number of samples according to each unit and faculty can be known as in table 2.

Table 2. Distribution of Research Samples

\begin{tabular}{ccccc}
\hline No & Unit/Faculty & $\begin{array}{c}\text { Number of } \\
\text { Population }\end{array}$ & $\begin{array}{c}\text { Sample } \\
\text { Calculation }\end{array}$ & $\begin{array}{c}\text { Number of } \\
\text { Sample }\end{array}$ \\
\hline 1 & Library & 16 & $16 / 234 * 71=4.79$ & 5 \\
2 & LPPM & 2 & $2 / 234 * 71=0.60$ & 1
\end{tabular}




\begin{tabular}{|c|c|c|c|c|}
\hline 3 & BPM & 2 & $2 / 234 * 71=0.60$ & 1 \\
\hline 4 & BAU & 36 & $36 / 234 * 71=10.28$ & 10 \\
\hline 5 & BAAK & 8 & $8 / 234 * 71=2.40$ & 2 \\
\hline 6 & BTI & 12 & $12 / 234 * 71=3.59$ & 3 \\
\hline 7 & BHP & 10 & $10 / 234 * 71=2.99$ & 3 \\
\hline 8 & BKA & 15 & $15 / 234 * 71=4.49$ & 4 \\
\hline 9 & BSDM & 7 & $7 / 234 * 71=2.10$ & 2 \\
\hline 10 & UPKK & 6 & $6 / 234 * 71=1.80$ & 2 \\
\hline 11 & BKMA & 5 & $5 / 234 * 71=1.50$ & 1 \\
\hline 12 & $\mathrm{BH} \& \mathrm{~K}$ & 2 & $2 / 234 * 71=0.60$ & 1 \\
\hline 13 & UKI Press & 2 & $2 / 234 * 71=0.60$ & 1 \\
\hline 14 & UPPB & 2 & $2 / 234 * 71=0.60$ & 1 \\
\hline 15 & FKIP & 10 & $10 / 234 * 71=2.99$ & 3 \\
\hline 16 & Faculty of Letters & 6 & $6 / 234 * 71=1.80$ & 2 \\
\hline 17 & Faculty of Economic & 10 & $10 / 234 * 71=2.99$ & 3 \\
\hline 18 & Faculty of Law & 9 & $9 / 234 * 71=2.69$ & 3 \\
\hline 19 & Faculty of Technique & 13 & $13 / 234 * 71=3.89$ & 4 \\
\hline 20 & Faculty of medicine & 40 & $40 / 234 * 71=11.38$ & 11 \\
\hline 21 & Academy of physiotherapy & 3 & $3 / 234 * 71=0.90$ & 1 \\
\hline 22 & Faculty of Social Politics & 6 & $6 / 234 * 71=1.80$ & 2 \\
\hline 23 & Postgraduate & 8 & $8 / 234 * 71=2.40$ & 2 \\
\hline 24 & Faculty of Nurse & 2 & $2 / 234 * 71=0.60$ & 1 \\
\hline \multirow[t]{2}{*}{25} & Banking Academy & 2 & $2 / 234 * 71=0.60$ & 1 \\
\hline & Number & 234 & & 71 \\
\hline
\end{tabular}

Data source: Annual Report of UKI's Rector, 2017

In accordance with the design of this study, namely using a survey, the data collection technique used is field research using an instrument in the form of a questionnaire. Questionnaires were made using a rating scale with five alternative answers, namely: (a) strongly agree / very often given a score of 5, (b) agree / often given a score of 4, (c) doubt / sometimes given a score of 3, (d ) do not agree / have been given a score of 2, (e) strongly disagree / never given a score of 1 . The data analysis technique used is descriptive data analysis techniques, data analysis with infresial statistics and test analysis requirements. The use of descriptive data analysis techniques is to obtain a description of the characteristics of the score distribution of each variable studied. Data analysis with descriptive statistics were presented in the form of frequency distribution tables and histograms. Central size includes average (mean), middle value (median) and mode (mode). The size of the spread includes variance and standard deviation (standard deviation). While inferential analysis / causal analysis is used to test the requirements of analysis and hypothesis by using path analysis. All hypothesis testing uses $\alpha=0.05$. Before testing the hypothesis, the normality test is done first, error estimation of regression using the Liliefors technique. To calculate the direct and indirect effects of independent variables on a dependent variable, reflected in the path coefficient. The endogenous variable in this study is service quality (Y). While exogenous variables include organizational commitment $\left(\mathrm{X}_{1}\right)$ and organizational citizenship behavior $\left(\mathrm{X}_{2}\right)$. The program used is the data analysis package contained in Microsoft Excel and the Statistical Package for the Social Science (SPSS) program.

\section{RESULT AND DISCUSSION}

Measurements in the study were carried out on service quality variables (Y) called endogenous variables, organizational commitment variables $\left(\mathrm{X}_{1}\right)$ as exsogenous variables and OCB variables $\left(\mathrm{X}_{2}\right)$ as intervening variables. The summary of each variable is presented in the following table.

Table 3. Summary of Descriptive Statistics

\begin{tabular}{lccc}
\hline \multicolumn{1}{c}{ Explanation } & Service Quality & Organization Commitment & OCB \\
\hline Average & 117.96 & 121.15 & 103.97 \\
Standard Error & 0.51 & 0.89 & 0.65 \\
Median & 118 & 121 & 104 \\
Mode & 118 & 120 & 105 \\
Standard & 4.31 & 7.47 & 5.51
\end{tabular}




\begin{tabular}{lccc} 
Deviation & & & \\
Variance & 18.6125 & 55.7900 & 30.3421 \\
Range & 19 & 34 & 34 \\
Lowest & 108 & 105 & 85 \\
Highest & 127 & 139 & 119 \\
Total score & 8375 & 8602 & 7382 \\
Sample Size & 71 & 71 & 71 \\
\hline
\end{tabular}

\section{Testing Requirements for Analysis}

The analytical tests conducted in this study include: a) Normality Test of Error Estimated Regression Data and b) Test of Significance and Linearity of Regression.

\section{a. Test the Normality of Estimated Error Data}

The recapitulation of the calculation results on the regression estimation error normality test as in the following table.

Table 4. Summary of Calculation Results for Estimated Normality Test

\begin{tabular}{|c|c|c|c|c|c|}
\hline \multirow{2}{*}{$\begin{array}{c}\text { Regression } \\
\text { Estimation Error }\end{array}$} & \multirow{2}{*}{$\mathbf{n}$} & \multirow{2}{*}{$\mathbf{L}_{\text {count }}$} & \multicolumn{2}{|c|}{$\mathrm{L}_{\text {table }}$} & \multirow{2}{*}{ Explanation } \\
\hline & & & $\alpha=0,05$ & $\alpha=0,01$ & \\
\hline $\mathrm{Y}$ on $\mathrm{X}_{1}$ & 71 & 0,0609 & 0,105 & 0,120 & Normally distributed \\
\hline $\mathrm{Y}$ on $\mathrm{X}_{2}$ & 71 & 0,0802 & 0,105 & 0,120 & Normally distributed \\
\hline $\mathrm{X}_{2}$ on $\mathrm{X}_{1}$ & 71 & 0,0652 & 0,105 & 0,120 & Normally distributed \\
\hline
\end{tabular}

Based on the prices of $\mathrm{L}_{\text {count }}$ and $\mathrm{L}_{\text {table }}$ above, it can be concluded that service quality for organizational commitment, service quality for organizational citizenship behavior, organizational citizenship behavior on organizational commitment originated from samples that are normally distributed.

\section{b. Test of Significance and Linearity of Regression}

The recapitulation of calculations result on significance and linearity test of regression can be seen in the following table.

Table 5. Summary of Significance Test Results and Regression Linearity Test

\begin{tabular}{|c|c|c|c|c|c|c|c|}
\hline \multirow{3}{*}{ Regression } & \multirow{3}{*}{ Regression Equation } & \multicolumn{3}{|c|}{ Significance Test } & \multicolumn{3}{|c|}{ Linearity Test } \\
\hline & & \multirow{2}{*}{$\mathrm{F}_{\text {count }}$} & \multicolumn{2}{|c|}{$\mathrm{F}_{\text {table }}$} & \multirow{2}{*}{$\mathrm{F}_{\text {count }}$} & \multicolumn{2}{|c|}{$\mathrm{F}_{\text {table }}$} \\
\hline & & & 0,05 & 0,01 & & 0,05 & 0,01 \\
\hline$Y$ on $X_{1}$ & $\hat{\mathrm{Y}}=84,87+0,27 \mathrm{X}_{1}$ & $19,86 * *$ & 3,98 & 7,02 & $0,80^{\mathrm{ns}}$ & 1,75 & 2,22 \\
\hline $\mathrm{Y}$ on $\mathrm{X}_{2}$ & $\hat{\mathrm{Y}}=77,48+0,39 \mathrm{X}_{2}$ & $22,65 * *$ & 3,98 & 7,02 & $1,48^{\mathrm{ns}}$ & 1,77 & 2,25 \\
\hline $\mathrm{X}_{2}$ on $\mathrm{X}_{1}$ & $\widehat{\mathrm{X}}_{2}=73,90+0,25 \mathrm{X}_{1}$ & $8,81 * *$ & 3,98 & 7,02 & $0,98^{\mathrm{ns}}$ & 1,75 & 2,22 \\
\hline
\end{tabular}

Information :

**: Very significant; ns: Non significant (linear regression)

\section{c. Path Coefficient Calculation}

The calculation of path coefficient is done by using the SPSS 22.0 for windows program, while the coefficient for each pathway in the structural relations model between variables illustrated in the table and the figure below are calculated and tested by the $t_{\text {test. }}$. The path diagram has 3 path coefficients, namely: $\mathrm{p}_{\mathrm{y} 1}, \mathrm{p}_{\mathrm{y} 2}$, and $\mathrm{p}_{21}$, so that there are 2 structural models obtained as follows:

\section{1) Path Coefficient in the First Model Substructure}

The structural equation formed in the first substructure model consists of 3 path coefficients from variables $X_{1}$ to $Y$ and $X_{2}$ to $Y$ in the form: $Y=p_{y 1} X_{1}+p_{y 2} X_{2}+p_{y} \varepsilon_{1}$. With magnitude $\left(\mathrm{R}_{\mathrm{y} .12}\right)^{2}=0,4467$ so $\mathrm{p}_{\mathrm{y}} \varepsilon_{1}=0,744$. So the form of structural equations in the first sub-structure model: $\mathrm{Y}=0,291 \mathrm{X}_{1}+0,285 \mathrm{X}_{2}+0,744$. The description of path coefficient estimation is explained in table 5 and visualized through the following figure 2. 
Table 6. SPSS Results on First Model

\begin{tabular}{|c|c|c|c|c|c|c|}
\hline & \multirow{2}{*}{ Model } & \multicolumn{2}{|c|}{$\begin{array}{c}\text { Unstandardized } \\
\text { Coefficients }\end{array}$} & \multirow{2}{*}{$\begin{array}{c}\text { Standardized } \\
\text { Coefficients }\end{array}$} & \multirow[t]{2}{*}{ t } & \multirow[t]{2}{*}{ Sig. } \\
\hline & & B & Std. Error & & & \\
\hline \multirow[t]{3}{*}{1} & (Constant) & 52,641 & 8,991 & & 5,855 & ,000 \\
\hline & $\begin{array}{l}\text { Organization } \\
\text { commitment }\left(\mathrm{X}_{1}\right)\end{array}$ & , 168 & ,056 & ,291 & 2,991 & ,004 \\
\hline & $\mathrm{OCB}\left(\mathrm{X}_{2}\right)$ & ,224 &, 079 & ,285 & 2,861 & ,006 \\
\hline
\end{tabular}

a Dependent Variable: service quality (Y)

The results of the estimation of the first structural model are then shown in the following figure:

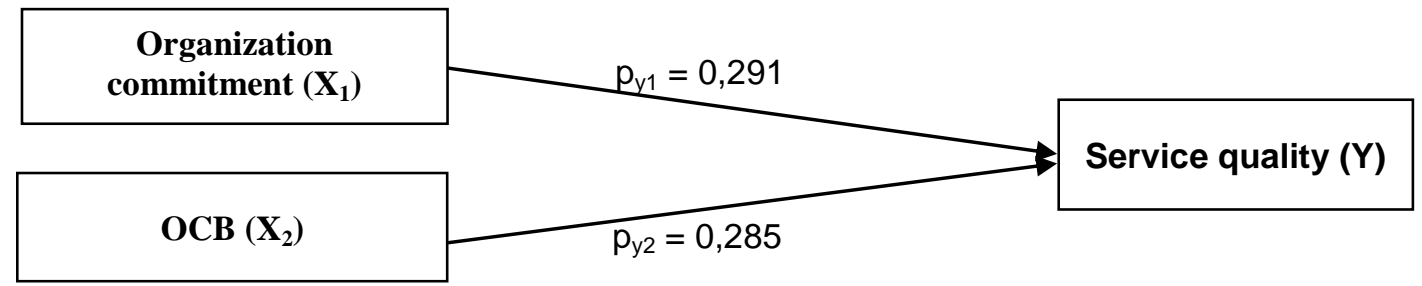

Figure 2. Empirical Path Structural Model 1

\section{2) Path Coefficient in the Second Model Substructure}

The structural equation formed in the second substructure model consists of 2 path coefficients from variables $X_{1}$ to $X_{2}$ in the form of: $X_{2}=p_{21} X 1 p_{2} \varepsilon_{1}$. With magnitude $\left(R_{2.12}\right)^{2}$ $=0.1835$ so $\mathrm{p}_{2} \varepsilon_{1}=0,904$. Then the shape of the structural equation in the second substructure model: $\mathrm{X}_{2}=0,266 \mathrm{X}_{1}+0,904$. The description of path coefficient estimation is explained in table 6 and visualized through the following picture:

Table 7. SPSS Results Second Model

\begin{tabular}{|c|c|c|c|c|c|c|}
\hline & \multirow{2}{*}{ Model } & \multicolumn{2}{|c|}{$\begin{array}{l}\text { Unstandardized } \\
\text { Coefficients }\end{array}$} & \multirow{2}{*}{$\begin{array}{c}\text { Standardized } \\
\text { Coefficients } \\
\text { Beta }\end{array}$} & \multirow[t]{2}{*}{$\mathbf{t}$} & \multirow[t]{2}{*}{ Sig. } \\
\hline & & B & Std. Error & & & \\
\hline \multirow[t]{2}{*}{2} & (Constant) & 57,342 & 11,972 & & 4,790 & ,000 \\
\hline & Organization commitment $\left(\mathrm{X}_{1}\right)$ & , 196 &, 084 & ,266 & 2,339 &, 022 \\
\hline
\end{tabular}

The estimation results of the second structural model are then shown on the following picture:

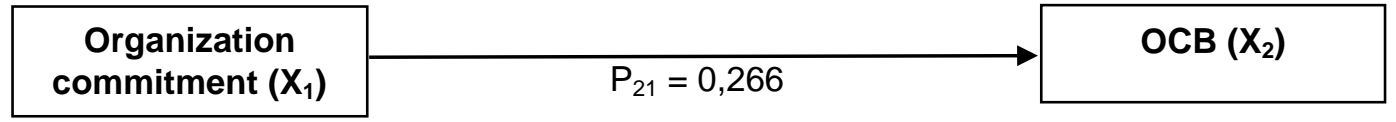

Figure 3. Empirical Diagram of Structural Model 2

Based on the calculation of path coefficients the influence of exogenous variables on endogenous variables in structural model 1 and structural model 2, the final results are obtained as follows:

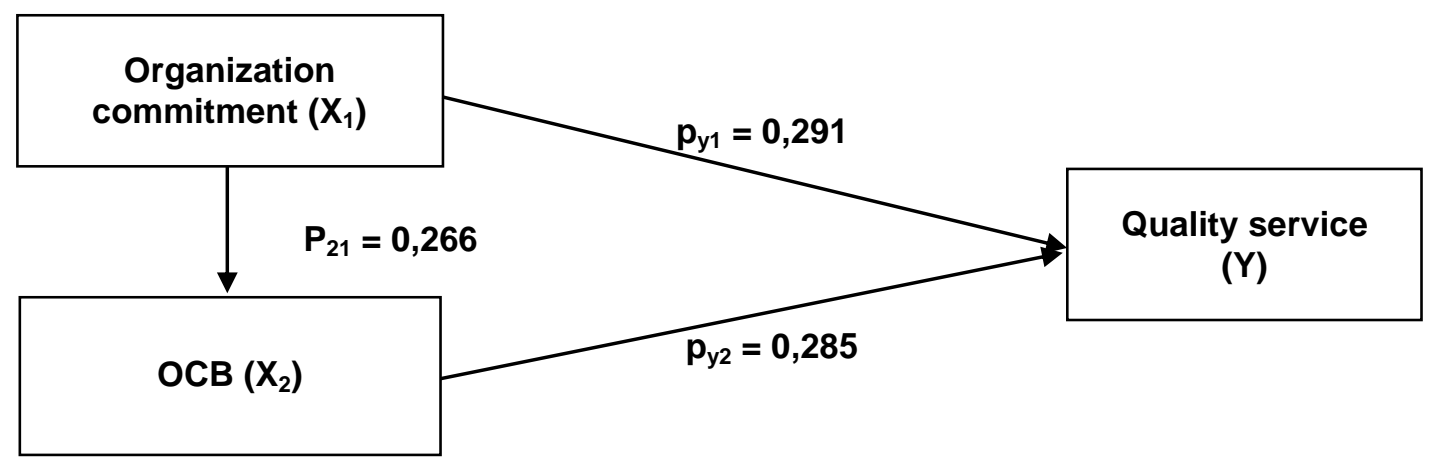




\section{Figure 4. Path Coefficient in Final Structural Models}

\section{d. Hypothesis Testing}

After calculation of the path coefficient is done through analysis of the causal structural model, to test the proposed hypothesis and measure the positive direct effect between variables, then the hypothesis conclusions are made. Withdrawal of hypothesis conclusions is based on the results of the calculation of the path coefficient and significance through the $t_{\text {test }}$ for each path studied. The following are described as follows:

\section{a. Positive Direct Effect of Organizational Commitment on Service Quality}

The hypothesis tested is:

$\mathrm{H}_{0}: \beta \mathrm{y} 1 \leq 0$

$\mathrm{H}_{1}: \beta y 1>0$

The coefficient value of organizational commitment path towards service quality is 0.291 with a $t_{\text {count }}$ of 2.99 . Because the $t_{\text {count }}$ is greater than the $t_{\text {table }}$ value at $\mathrm{dk}=67$ for $\alpha=0.01$ at 2.65 then $\mathrm{H}_{0}$ is rejected and $\mathrm{H}_{1}$ is accepted, which means there is a very significant positive direct effect of the organizational commitment on the service quality.

\section{b. Positive Direct Effect of OCB on Service Quality}

The hypothesis tested is:

$\mathrm{H}_{0}: \beta \mathrm{y}_{2} \leq 0$

$\mathrm{H}_{1}: \beta \mathrm{y}_{2}>0$

OCB path coefficient value for service quality is 0.285 with a $t_{\text {count }}$ of 2.86 . Because the $t_{\text {count }}$ is greater than the $t_{\text {table }}$ value at $\mathrm{dk}=67$ for $\alpha=0.01$ at 2.65 then $\mathrm{H}_{0}$ is rejected and $\mathrm{H}_{1}$ is accepted, which means there is a very significant positive direct effect of OCB variables on service quality.

\section{c. Positive Direct Effect of Organizational Commitment on OCB}

The hypothesis tested is:

$\mathrm{H}_{0}: \beta_{21} \leq 0$

$\mathrm{H}_{1}: \beta_{21}>0$

The coefficient of organizational commitment path to OCB is 0.266 with a $t_{\text {count }}$ of 2.34 . Because the $t_{\text {count }}$ is greater than the $t_{\text {table }}$ at $\mathrm{dk}=68$ for $\alpha=0.05$ at $2.00, \mathrm{H}_{0}$ is rejected and $\mathrm{H}_{1}$ is accepted, which means there is a significant positive direct effect of the organizational commitment variable on the OCB.

From the results of the analysis and calculation process carried out on the direct influence section, it can be summarized as follows:

Table 8. Direct Effects on Inter-Variable

\begin{tabular}{|c|c|c|c|c|c|c|}
\hline \multirow{2}{*}{ No } & \multirow{2}{*}{ Direct effect } & \multirow{2}{*}{$\begin{array}{c}\text { Path } \\
\text { Coefisien }\end{array}$} & \multirow{2}{*}{$\mathbf{t}_{\text {count }}$} & \multicolumn{2}{|c|}{$\mathbf{t}_{\text {table }}$} & \multirow{2}{*}{ Summary } \\
\hline & & & & $\alpha=\mathbf{0 , 0 5}$ & $\alpha=\mathbf{0 , 0 1}$ & \\
\hline 1. & $\mathrm{X}_{1}$ on $\mathrm{Y}$ & 0,291 & $2,99 * *$ & 2,00 & 2,65 & $\begin{array}{l}\text { Organization commitment has a } \\
\text { significant positive direct effect } \\
\text { on service quality }\end{array}$ \\
\hline 2. & $\mathrm{X}_{2}$ on $\mathrm{Y}$ & 0,285 & $2,86 * *$ & 2,00 & 2,65 & $\begin{array}{l}\text { Organizational citizenship } \\
\text { behavior (OCB) has a significant } \\
\text { positive direct effect on service } \\
\text { quality }\end{array}$ \\
\hline 5. & $\mathrm{X}_{1}$ on $\mathrm{X}_{2}$ & 0,266 & $2,34 *$ & 2,00 & 2,65 & $\begin{array}{l}\text { Organization commitment has a } \\
\text { significant positive direct effect } \\
\text { on Organizational citizenship } \\
\text { behavior }(O C B)\end{array}$ \\
\hline
\end{tabular}

$*$ = significant $\left(\mathrm{t}_{\text {count }}>\mathrm{t}_{\text {table }}\right.$ at $\left.\alpha=0.05\right)$

$* *$ = very significant $\left(\mathrm{t}_{\text {count }}>\mathrm{t}_{\text {table }}\right.$ at $\left.\alpha=0.01\right)$

In addition to analyzing the direct effects of organizational commitment, and organizational citizenship behavior on service quality, there are indirect effects of organizational commitment to service quality through organizational citizenship behavior.

\section{Through OCB}

d. Positive Indirect Effects of Organizational Commitment on Service Quality

The hypothesis tested is: 
$\mathrm{H}_{0}: \beta \mathrm{y}_{2} \cdot \beta_{21} \leq 0$

$\mathrm{H}_{1}: \beta \mathrm{y}_{2} \cdot \beta_{21}>0$

Positive indirect effects of organizational commitment on service quality through organizational citizenship behavior (OCB) are the results of organizational commitment path coefficients on OCB ( $\beta 21)$ and OCB path coefficients on service quality $(\beta$ y2), are: $(0.266)$ $(0.285)=0.076$. Because the direct effect of organizational commitment on service quality is 0.291, the total effect given by organizational commitment to service quality through OCB is $0.291+0.076=0.367$. Based on the calculation results, the indirect effect value is greater than the direct effect value, this indicates that there is an indirect effect of the variable organizational commitment on service quality through significant OCB.

\section{Discussion of Research Results}

The results obtained after conducting a model analysis, are used as a basis in answering the hypotheses and drawing conclusions in this study. The explanation of the answers to these hypotheses can be described as follows:

a. Positive Direct Effect of Organizational Commitment $\left(X_{1}\right)$ on Service Quality (Y)

The finding of the first hypothesis result is that organizational commitment has a positive direct effect on service quality. Based on these findings, it can be concluded that service quality is directly influenced positively by organizational commitment. Increasing organizational commitment will result in improved service quality. This is in accordance with the conclusions conveyed by Robbins and Judge that reinforcement theory has a record in predicting service quality, and optimal service quality will be achieved if employees have a commitment to repeat behavior that can increase customer satisfaction. In addition, the results of this study are reinforced by Somad's statement that organizational commitment has a positive and significant effect on employee service quality so that the higher the organizational commitment, the higher the quality of employee services (Somad, 2013: 337)

Thus the findings of facts and data in the analysis of this study increasingly support the direct influence between organizational commitment and service quality.

\section{b. Positive Direct Effect of OCB $\left(\mathbf{X}_{2}\right)$ on Service Quality (Y)}

The finding of the second hypothesis result is that OCB has a direct and positive effect on service quality. Based on these findings it can be concluded that service quality is directly influenced positively by OCB. Increasing OCB will result in improved service quality. The results of this study are in line with the opinions of several experts including Robbins and Judge, who stated that organizations that have employees who have good Organizational Citizenship Behavior will have better performance than other organizations, so they can be expected to show high service quality in the form of behavior reliable in the job, responsive to needs, provide a assurance of trust, and empathize with customers. The same opinion was said by Djati in his research on administrative or administrative employees and students from six private universities in Surabaya who had more than 5,000 students, that OCB had a positive effect on service quality so as to provide satisfaction to customers at several universities in East Java (Djati, 2011: 18). The results of the study show that the quality of service provided by administrative employees to private university students in Surabaya is good. In addition, the results showed that moral, commitment, and motivation significantly affected Organizational Citizenship Behavior which subsequently affected service quality.

Thus the findings of facts and data in the analysis of this study further support the direct influence between organizational citizenship behavior (OCB) and organizational quality.

\section{c. Positive Direct Effect of Organizational Commitment $\left(X_{1}\right)$ on OCB $\left(X_{2}\right)$}

The finding of the thirth hypothesis result is that organizational commitment has a positive direct effect on OCB. Based on these findings, it can be concluded that OCB is directly influenced positively by organizational commitment. Increasing organizational commitment will lead to increased OCB. The results of this study are in line with the opinion of Robbins and Judge that OCB can arise from various factors in the organization, including because of the organizational commitment of high employees. When an employee has satisfaction with his job, then the employee will work optimally in completing his work, even doing some things that might be beyond his duties. Likewise when an employee has a high commitment to his organization, the person will do anything for the success of his company 
because the employee has confidence in his organization. Employees who have a commitment to the company, then the employee will feel satisfaction in working and willing to do for the progress of the company. The results of the analysis were also supported by Sucahya and Suana (2016: 7352) who conducted research on employees of the Denpasar One-Stop Integrated Licensing and Investment Services Agency (BPPTSP \& PM). The results of the study concluded that organizational commitment had a positive and significant effect on organizational citizenship behavior at Denpasar City's One Stop Licensing and Investment Services (BPPTSP \& PM) employees. Thus the findings of facts and data in the analysis of this study further support the direct influence between organizational commitment and OCB.

\section{d. Positive Indirect Effects of Organizational Commitment on Service Quality Through OCB}

The finding of the fourth hypothesis result is that organizational commitment has a positive indirect effect on service quality through OCB. So that to improve service quality can be done by increasing organizational commitment so that OCB increases. This means that organizational commitment is important to improve service quality

\section{CONCLUSION}

Based on the analysis carried out in the previous section, the findings in this study are as follows: a) Organizational commitment has a very significant positive direct effect on service quality. These findings indicate that the increasing commitment of employees to the organization will have an impact on improving the quality of service for employees of the Indonesian Christian University. The results of this study are in line with the opinions of Rismi Somad (2013: 337) who conducted a study of four-star hotel employees in the city of Bandung. The results of the study showed that organizational commitment had a positive and significant effect on the quality of employee services in four-star hotels in the city of Bandung; b) OCB has a very significant positive direct effect on service quality. These findings indicate that increasing OCB will have an impact on improving the quality of services for Indonesian Christian University employees. The results of this study are in line with the opinions by Djati (2011: 18) in his research on administrative employees and students from six private universities in Surabaya who had more than 5,000 students, that OCB had a positive effect on service quality so as to provide satisfaction to customers at several universities in East Java; c) Organizational commitment has a significant positive direct effect on OCB. These findings indicate that increasing employee commitment to the organization will have an impact on increasing OCB for Indonesian Christian University employees. The results of this study are in line with the opinion of Sucahya and Suana (2016: 7352) who conducted research on employees of the Denpasar One-Stop Integrated Licensing and Investment Services Agency (BPPTSP \& PM). The results of the study concluded that organizational commitment had a positive and significant effect on organizational citizenship behavior at Denpasar City's One Stop Licensing and Investment Services (BPPTSP \& PM) employees. In addition, the finding that there is an indirect effect of organizational commitment on service quality through OCB. So that to improve the quality of service for Indonesian Christian University employees can be done by increasing organizational commitment so that OCB increases. 


\section{REFERENCES}

Adekola. (2012). The Impact of Organizational Commitment on Job Satisfaction: A Study of Employees at Nigerian Universities. International Journal of Human Resource Student, Vol. 2, No. 2.

Ahmadia. (2017). Effect of Competitive Advantage and Service Quality on Satisfaction and Loyalty of Visitors to Water Tourism Objects 'Owabong Purbalingga. Jurnal Ekonomi Manajemen Sumber Daya, Vo. 19, No. 1.

Akbar, Musadieq dan Mukzam. (2017). Effect of Organizational Commitment on Performance (Study of PT Pelindo Surabaya Employees). Jurnal Administrasi Bisnis $(J A B)$ Fakultas Ilmu Administrasi Universitas Brawijaya Malang, Vol. 47, No.2.

Aledeinat \& Alrfou. (2017). The Effects of Organizational Support and Organizational Commitment on Organizational Citizenship Behaviour: (A conceptual framework)", International Journal of Management Sciences and Business Research, Vol. 6, Issue 5.

Allen \& Meyer. (1990). The measurement and antecedents of affective,continuance, and normative commitment. Journal of Occupational Psychology.

Amri \& Shabri. (2015). Contribution of Job Satisfaction, Organizational Climate and Organizational Commitment to the Quality of Medical Services at the Regional Public Service Agency (BLUD) of Aceh Mental Hospital. Jurnal Manajemen Pascasarjana Universitas Syiah Kuala. Vol. 4, No. 3.

Apriliana, Hamid \& Hakam. (2013). Effect of Motivation and Organizational Commitment on Employee Performance. Jurnal Administrasi Bisnis (JAB), Vol. 1, No. 1.

Bahrami et. al. (2016). Role of Organizational Climate in Organizational Commitment: The Case of Teaching Hospitals. Osong Public Health Res Perspect.

Colquitt, Lepine \& Wesson. (2011). Organizational Behavior, Improving Performance and Commitment in the Workplace, second Edition. New York: Mc Graw Hill.

Darto. (2014). The Role of Organizational Citizenship Behavior (OCB) in Enhancing Individual Performance in the Public Sector: A Theoretical and Empirical Analysis. Jurnal Borneo Administrator, Vol. 10, No. 1.

Djati, S. P. (2011). The influence of the Organizational Citizenship Behavior towards the Service Quality Performances of The Univercities in Surabaya-Indonesia. Jurnal Aplikasi Manajemen, Vol. 9, No. 1.

Djati, S. P. (2014). Antecedent Variables of Organizational Citizenship Behavior (OCB) and Its Impact on Service Quality.Jakarta: Kaylin Cahaya Internasional.

Fatrunisah. (2015). Quality of Health Services at Malinau Seberang Community Health Center, North Malinau District, Malinau District. eJournal Ilmu Administrasi Bisnis.

George \& Jones. (2012). Understanding and managing organizational behavior, Sixth Edition. New Jersey: Prentice Hall.

Ghanbari \& Eskandari. (2014). Organizational Climate, Job Motivation and Organizational Citizenship Behavior. International Journal of Management Perspective, Vol.1, No.3.

Handayani. (2013). Analysis of the Effect of Technical Quality, Functional Quality and Image of Institutions on Satisfaction of Service Users Unit of the State Wealth Management Section (KPKNL) Jambi. Jurnal Dinamika Manajemen, Vol. 1, No.1.

Hapsari. (2010). The Role of Organizational Citizenship Behavior in Mediating the Influence of Employee Satisfaction and the Practice of Human Resource Management on the Quality Services of Five-Star Hotels in Central Jakarta. Jurnal Manajemen dan Pemasaran Jasa, Volume 3.

Harjati \& Venesia. (2015). Effect of Service Quality and Price Perception on Customer Satisfaction at Tiger Air Mandala Airlines. E-Journal WIDYA Ekonomika, Vol. 1, No. 1.

Huang \& Lee. (2015). The Influences of Employee Service Quality and Organizational Commitment on Financial Performance as Exemplifed By Taiwan-List International Tourist Hotels. International Journal of Information Technology and Business Management, Vol. 34, No.1.

Iliea. (2014). Organizational citizenship behaviour, work satisfaction and Employees personality. Journal Procedia-Social and Behavioral Sciences. 
Ivancevich, Konopaske, \& Matheson. (2005). Perilaku Dan Manajemen Organisasi. Jakarta: Erlangga.

Kamalinasab, Sami, Zendedel. (2017). The effect of internal marketing on service quality with emphasis on moderator role of organizational citizenship behavior (case study: postal services in khorasan razavi province). Revista QUID (Special Issue).

Khaleh \& Naji. (2016). The relationship between organizational commitment components and organizational citizenship behavior in nursing staff. International Journal of Medical Research \& Health Sciences.

Khoirista, Yulianto \& Mawardi. (2015). Effect of Service Quality on Customer Satisfaction (Survey of Surabaya FEDEX Express Customers).Jurnal Administrasi Bisnis (JAB) Universitas Brawijaya Malang, Vol. 25, No. 2.

Khosravi \& Mohammadi. (2017). The effects of workplace spirituality and stress on organizational citizenship behavior and organizational anti-citizenship behavior and its relationship with customer loyalty and quality of service (case study: Madarin hospital). Revista QUID (Special Issue).

Kopertis. (2014). Hasil Peringkat Perguruan Tinggi Indonesia. Retrieved from http://www.kopertis 12.or.id/2014/01/22/hasil-peringkat-perguruan-tinggi-indonesiaversi-4icu-tahun-2014.html. On March, 08, 2017.

Kotler \& Keller. (2012). Marketing Management. 14th Edition. Prentice Hall.

Luthans. (2011). Organization Behavior an Evidance Base Approach, Twelfth Edition. New York: McGraw-Hill.

McShane \& Glinow. (2011). Organizational Behavior: Emerging knowledge and Practice For The Real World. New York: McGraw-Hill.

Mmatle \& Shonhe. (2017). Customer's perception of Service Quality and its impact on reputation in the hospitaly industry. African Journal of Hospitaly, Tourism and Leisure, Vol. 6.

Murni. (2011). Customer Satisfaction Analysis of Quality of Pest Control Services By CV. Jaya Putra Mandiri Makassar. Jurnal Ekonomi Balance, Vol. 7, No. 2.

Nengsih, Hadiyanto \& Murni. (2013) "Effect of Commitment, Morale, Motivation and Organizational Climate on Service Quality Through Organizational Citizenship Behavior at University of Bengkulu Employees. Jurnal Ilmiah Manajemen The Manager Review, Vol. 15, No. 7.

Nuhung. (2011). Study of Service Quality and Relational Marketing, Its Effects on Customer Satisfaction and Loyalty of Sharia Banks in the City of Makassar. Jurnal Ekonomi Balance, Vol. 7, No. 2.

Nurandiri \& Laturava. (2014). Influence Analysis of Organizational Commitment to Employee Performance (Study of Jakarta Public Housing Officials)", Jurnal Studi Manajemen dan Organisasi, Vol. 78-79.

Ogunnaike. (2011). Assessing the Effect of Organizational Commitment on Service Quality; a Study of Customer-Contact Employee. Global Journal of Management And Business Research, Vol.11, Issue 2.

Ortiz, et al. (2015). Relationship between organizational commitments and organizational citizenship behaviour in a sample of private banking employees", International Journal of Sociology and Social Policy, Vol. 35, Issue: 1/2.

Panjaitan \& Yuliati. (2016). Effect of Service Quality on Customer Satisfaction at JNE Bandung Branch. DeReMa Jurnal Manajemen Universitas Telkom, Vol. 11, No. 2.

Parasuraman, et al. (1998). A Multiple-Item Scale for Measuring Consumer Perceptions of Service Quality. Journal of Retailing, Vol. 64, No.1.

Prabhakar \& Ram. (2011). Antecedent HRM Practices For Organization Commitment. International Journal of Business and Social Science, Vol. 2.

Putra \& Supartha. (2017). Effect of Job Satisfaction and Organizational Commitment on Organizational Citizenship Behavior in Bali's Green Garden Hotel. E-Jurnal Manajemen Unud, Vol. 6, No. 5.

Rahayu. (2016). Effect of Work Culture, Integrity and Trust in Organizational Citizenship Behavior at Lecturers in Jakarta State University. Disertasi, Universitas Negeri Jakarta.

Robbins \& Judge. (2013). Organization Behavior. USA: Pearson Education, Inc. 
Rusyandi. (2016). Engagement Commitment to ITQ. International Journal of Business and Management Invention, Vol. 5.

Setiawan. (2015). The Influence of Organizational Climate on Employee Performance at Executive Level at PT Pusri Palembang Operations Division. PSIKIS Journal Psikologi Islam, Vol. 1, No. 1.

Setyaningrum. (2017). Relationship between Servant Leadership in Organizational Culture, Organizational Commitment, Organizational Citizenship Behaviour and Customer Satisfaction. European Research Studies Journal, Vol. XX, Issue 3A.

Somad, R. (2013). The Influence of Organizational Culture and Organizational Commitment to the Quality of Four-Star Hotel Staff Services in the City of Bandung (Survey of Employee Customer Services). Jurnal Bisnis \& Manajemen, 9(3).

Sucahya \& Suana. (2016). Effect of Employee Morals and Organizational Commitment on Organizational Citizenship Behavior. e-Jurnal Manajemen Unud, Vol. 5, No. 11.

Sugiyah. (2018). Analysis of the Influence of Services on Customer Satisfaction in KFC Restaurants in Gongseng, East Jakarta. Jurnal Penelitian Ilmu Manajemen, Vol. 1, No. 1.

Tambe \& Shanker. (2014). A Study of Organizational Citizenship Behaviour (OCB) and Its Dimensions: A Literature Review. International Research Journal of Business and Management - IRJBM, Vol. 1.

Ticoalu. (2013). Organizational Citizenship Behavior (Ocb) and Organizational Commitment Influence on Employee Performance. Jurnal EMBA Jurusan Manajemen Universitas Sam Ratulangi Manado, Vol.1, No.4.

Titisari. (2014). The Role of Organizational Citizenship Behavior (OCB) in Improving Employee Performance. Jakarta: Mitra Wacana Media.

Wagner \& Hollenbeck. (2010). Organizational Behavior: Securing Competition Advantage. New York: Routledge.

Wibowo. (2015). Behavior in Organizations. Jakarta: Rajagrafindo Persada. 